\title{
1
}

\section{The Growing Gap}

\begin{abstract}
In this chapter Cilliers introduces the growing divergence in income and other indices of well-being between Africa and the Rest of the World. He touches on various aspects such as extreme poverty and Africa's marginal role in the global economy and illustrates the challenge by comparing the divergent experiences of South Korea and Ghana in demographics and income, before moving to introduce matters relating to productivity, digitisation, agriculture and manufacturing. The chapter presents key characteristics of Africa compared to other countries and regions to 2040, defines some of the terms, introduces the International Futures forecasting platform that is used for the forecasts, and the structure of the book.
\end{abstract}

Keywords Africa · Forecasts - Scenarios - Africa - Ghana - South Korea · Economic size - Population - Agriculture - Manufactures - Demographics · Poverty · Growth

I founded the Institute for Security Studies in 1991 as an effort to contribute to policy development in post-apartheid South Africa. Reflected in our name we focussed our efforts on policies and measures to research and recommend improvements domestically, in the region and eventually to contribute to stability and security in Africa. From about 1994 I worked intimately with the secretariat of the Organization of African Unity, today the Commission of the African Union, sometimes spending week on week in Addis Ababa, attending an incalculable number of planning and strategy sessions there and elsewhere. 
The end of the Cold War was a heady time in Africa, offering the prospect for an end to the proxy wars that had been fought across the length and breadth of the continent for decades. But over time my sense of disillusionment increased at the lack of focus on the underlying drivers of insecurity.

We helped the OAU/AU develop numerous policies and plans on peacekeeping, combatting terrorism, organised crime, security sector reform and the establishment of various systems such as those related to early warning. My sense of frustration increased with each effort. It's not that things were not improving. Africa is, today, significantly more stable than the years leading up to the end of the Cold War when large-scale armed conflict was the order of the day. It's just that we forever seemed to be dealing with the symptom of the problem. Like a band-aid plaster we were trying to stop the bleeding but did little to help the patient recover and avoid a relapse. And everything was a crisis with little time spent on reviewing the strategic choices being made and even less on monitoring implementation.

After stepping down as head of the Institute in 2015 I was able to devote my full attention to the study of causality and trends, something I had by then been dabbling in for several years. Following a Fulbright fellowship in the USA, my second career at the Institute, now as chair of the ISS board of trustees and as head of the programme on African Futures \& Innovation, has allowed me to indulge in trend analysis, looking much more broadly at the drivers and the solutions to Africa's slow progress and the measures required to accelerate broad progress in governance and development.

For successive decades I've paid regular visits to many countries across the continent, travelling from our head office in Pretoria. I can confirm the good news story of a vibrant and dynamically developing continent, particularly in its cities. Gleaming new airports, bustling streets, traffic jams and youthful vigour and life can be found from Addis Ababa and Lusaka to Nairobi and Lagos. A far cry from the stereotype generally conveyed in most Western media.

Africa is undoubtedly experiencing a broad-based improvement in human well-being, which is reflected in a number of health indicators such as declining rates of infant mortality, improvements in life expectancy and others. In this regard, Africa is catching up with global averages.

However, looking at the bigger picture, one can argue that this is largely because rapid improvements at lower levels of development are easier to achieve while continued improvements in rich countries are more difficult at their much higher levels. On most other indicators of well-being the gap between Africa and the rest of the world is actually increasing. In the 
words of colleague Julia Bello-Schünemann 'things are getting better, but not everywhere and not for everybody. ${ }^{1}$

If Africa could have talked itself into development it would be doing very well. But only rarely do the many plans and visions translate into reality. These plans and visions include the 1980 Lagos Plan of Action for the Economic Development of Africa, the New Partnership for Africa's Development (NEPAD) and recently Agenda 2063, the long-term development vision of the African Union.

\section{The Growing Income Divergence}

This book has its origin in the growing gap in average gross domestic product (GDP) per capita in Africa and the rest of the world. GDP per capita is a key indicator of progress since it reflects economic productivity and the relative standard of living. It is a relatively crude measure as it does not take the quality of life into account or the distribution of the economic output among the population. It is calculated by simply dividing the total economic output of a country (GDP) in a year by the total population. Because of this simplicity it remains the most popular measure of national economic productivity that allows easy comparisons between different countries.

In 1960, generally considered the start of the postcolonial era, GDP per capita in Africa was about half of the average in the rest of the world and the gap has been growing larger ever since. It fell to below $40 \%$ in 1986 and below 30\% in 2011. In fact, average GDP per capita actually declined by more than US\$600 from 1980 to 1995 . Then, from 1995 to the global financial crisis in 2008/2009, Africa experienced its most sustained period of growth since 1960. But, in 2018, the standard year of reference used in this book, GDP per capita in Africa is still only $27 \%$ of the average in the rest of the world. By 2040, GDP per capita in Africa is projected to be less than one-quarter of the average for the rest of the world. ${ }^{2}$

Figure 1.1 presents this information in a line graph that compares the average GDP per capita in Africa with that in the rest of the world from 1960 to 2040. Up until 2018 the underlying data originates with the World Bank and thereafter it is a forecast.

\footnotetext{
${ }^{1}$ Cilliers, J., Bello-Schünemann, J., Donnenfeld, Z., Aucoin, C., and Porter, A. 2017. Institute for Security Studies. [Online] Available at: https://issafrica.org/research/policy-brief/african-futures-key-tre nds-to-2035.

${ }^{2}$ Using purchasing power parity.
} 


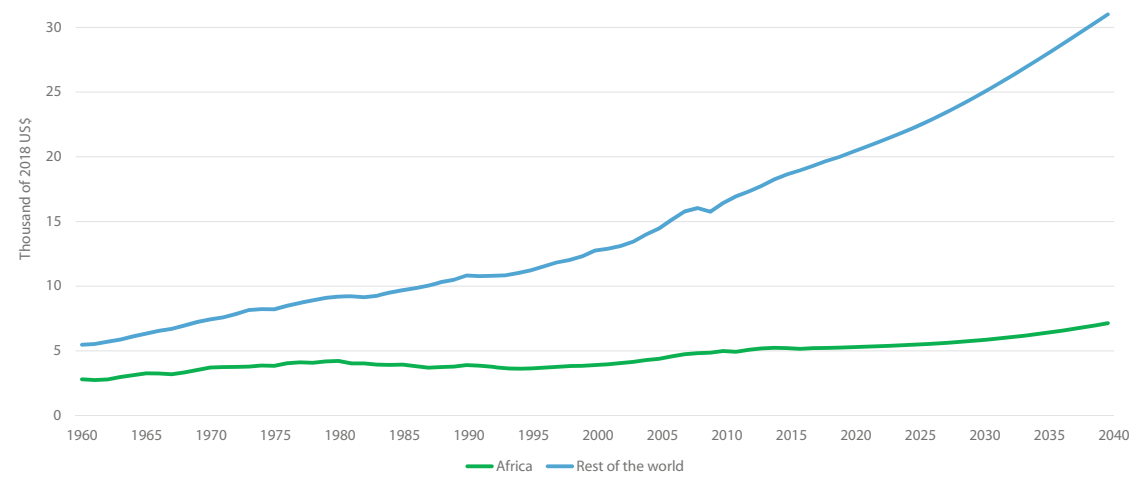

Fig. 1.1 GDP per capita in purchasing power parity: from 1960 with a forecast to 2040 (Source IFs version 7.45 initialised from World Bank, World Development Indicators, 2018)

Like the jaws of a yawning crocodile, it paints a picture of increasing divergence. At the ISS I use this graph at the start of most of my presentations on African futures to illustrate the progress made and the challenges that lie ahead.

The increasing divergence between the trend in GDP per capita in Africa versus the average for the rest of the world correlates with many other indices of human development or well-being, such as average levels of education and various measures of health. Since this book is finalised in mid-2020 the graph does not yet capture the impact of the COVID-19 pandemic, sure to eventually represent a global and African kink similar to that evident from the 2008/2009 financial crisis or worse.

We therefore find ourselves in a situation where Africa is progressing slower even than other developing regions such as South America and South Asia. The future is always clouded by uncertainty. However, based on our understanding of where Africa is today and the correlation between variables across different development systems, we have a good sense of where Africa is currently heading.

For long-term forecasting, I use a general time horizon to 2040, which is well beyond the time horizon of the 2030 Agenda for Sustainable Development but significantly shorter than Agenda 2063. While I will consistently benchmark progress to 2040, in certain areas, such as climate change, demographics and projected waves of democracy and/or autocracy, the presentation of trends extend over longer time horizons, in some instances to the end of the century. 
So why does Africa continue to slip further and further behind global averages of well-being and what could be done about it?

My goal with this book is to present a cohesive story about human and economic development in Africa revolving around three essential questions: (1) Where does Africa find itself today in relation to the situation elsewhere in the world and generally, what explains this state of affairs? (2) Given historical trends and what we know about the world, where do we think Africa will be in 2040? Is this future really inevitable? And ultimately, (3) What can be done to improve this trajectory and create a better tomorrow for the continent?

Clearly something drastic is needed. Doing more of the same is not going to lead to tangible progress. The momentum from a burgeoning population, the continued growth of China, India and others, the swift pace of technological change, the impact of climate change and other disruptive events such as pandemics, presents a complex picture. On the one hand there are huge opportunities in electricity generation and access, expansion of mobile broadband networks and better access to financial services. On the other, it is evident that Africa will suffer immensely from the impact of changes in the global climate. What is clear is that on its current trajectory, Africa could be left further behind as development accelerates elsewhere particularly if crises, such as the COVID-19 pandemic hammer the developing world more seriously than the developed world.

In essence this book describes and models the impact of a series of fundamental transitions in health, demographics, agriculture, education, manufacturing, technology, trade integration, stability and governance that is needed if Africa is to narrow and start closing the gap in development between itself and the rest of the world.

Governments need to intervene in many areas. They are supposed to improve education, spend on health, build infrastructure and provide security. But since resources are limited the most important policy question is what to prioritise? What gives the best return on investment? And what is the role of the private sector and external agencies?

These choices imply that some degree of trade-off is inevitable-some short-term pain will accompany long-term gain. This is an issue to which I return in the concluding chapter. 


\section{South Korea and Ghana}

A comparison between the reasons for the divergent development trajectories of Ghana and South Korea-one that is often used in academic literatureemphasises the difference in outcomes and the role that demographics, policy choices and leadership played. The difference is presented in Fig. 1.2 and illustrates the extent to which the demographic dividend and average incomes in these two countries coincide. When Ghana and South Korea gained independence, South Korea was actually poorer than Ghana, but today its average income levels is nine times that of Ghana as measured using GDP per capita in purchasing power parity.

With a focus on food self-sufficiency, basic education, family planning and the provision of basic health care, South Korea managed to rapidly reduce its rates of fertility and, as a result, experienced a steady increase in the number of working age persons to dependents. Thanks to this demographic dividend, the ratio of working age persons to dependents went from 1.2 in the
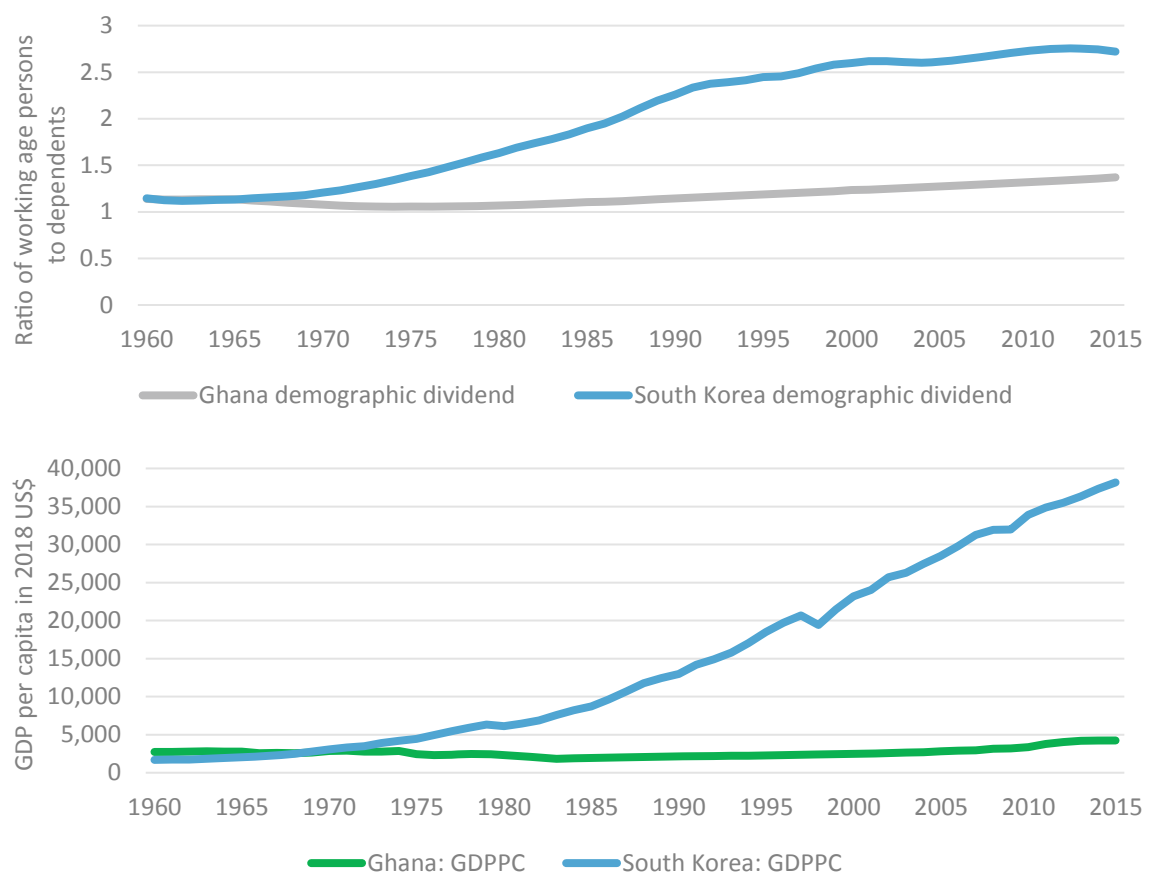

Fig. 1.2 Ghana vs South Korea: income per person vs demographic dividend: 1960 to 2015 (Source IFs 7.45 initialising from World Bank, World Development Indicators, 2018 and UN Population Division, World Population Prospects: The 2017 Revision) 
late 1950 s to a recent peak of almost 2.8 - an extraordinary high ratio only achieved by China and the Asian Tiger economies in modern history.

Ghana has always had a very low ratio of working age persons. Even in 2018 it is less than 1.4, although it is improving. In retrospect it is perhaps not that surprising that Korea developed so quickly from around 1980, but the foundation for this growth was already laid in the late 1950s and 1960s. Not everything went smoothly, however, and the impact of the 1997-1998 Korean financial crisis on incomes is plain to see as the graph briefly dips in its otherwise smooth upward trajectory.

South Korea's Saemaul Undong, the New Village Movement, played an important role in its spectacular growth. This was a community-driven selfhelp movement facilitated by the government. It is not an approach where the government sought to pursue prestige projects meant to leapfrog Korea into an industrial age (as was tried in Ghana in the 1960s). Rather, it was an initiative that first, and primarily, sought to change the mindset at community level towards self-help and self-reliance.

Once Korea had achieved food self-sufficiency and started making steady agricultural and educational progress, it embarked on an export-led manufacturing pathway, starting at a very basic level. ${ }^{3}$

South Korea had another advantage. It had no oil, gas or other large-scale natural resource. All it had was its people. By comparison Ghana, originally called the Gold Coast as a British colony until independence in 1957, has always had the potential of benefiting from its much more significant natural resources. Except that it did not.

It is now well-established that enclave economics such as those that develop around the oil and gas industry in particular, does not work. The largesse of oil and natural gas have had a particularly deleterious impact on countries like Nigeria, Angola, Equatorial Guinea, and shortly Mozambique. This resource curse occurs when the main driver of the economy creates small, highly developed bubbles with no forward or backward linkages to the domestic economy but serve to prop up the exchange rate and effectively makes it impossible to produce local goods at competitive rates. The only people that benefit are foreign investors, local frontmen and -women, and corrupt government officials.

Saemaul Undong was instituted by an authoritarian government and it is seldom mentioned in mainstream analysis of South Korea's escape from underdevelopment. Generally, economic development was the first priority of the South Koreans. This stands in stark contrast to the famous slogan

${ }^{3}$ See Park, J.-D., 2019. Re-Inventing Africa's Development Linking Africa to the Korean Development Model. Basingstoke: Palgrave Macmillan. 
of Ghana's independence leader, Kwame Nkrumah, to first seek 'the political kingdom and all things shall be added unto you'. ${ }^{4}$ When comparing the general human development indicators of Ghana and South Korea today, the different results are demonstrable.

Ghana and South Korea were, for much of their independent history, autocratic countries and suffered under colonialism with the latter additionally suffered a debilitating war from 1950 to 1953 . Both became hugely corrupt after independence, but whereas South Korea had a leadership that prioritised development and self-help, Ghana did not. Democracy played no role in Korea's development but is, today, highly valued in much of Africa because the alternative, autocracy, has had disastrous results on the continent.

This points to the unique challenges that Africa faces when compared to developing Asia where industrialisation occurred under autocratic but generally developmentally oriented regimes. Here leaders could discount the popular discontent associated with the disruptive changes required for productivity improvements. The ruling elite can introduce tariff protection to support a particular sector or industry and more easily phase it out once that goal has been achieved than in a democracy.

The world of the mid-twentieth century is, however, very different to the twenty-first century. It is not possible to roll back democracy in Africa, even if it were desirable from a narrow economic mindset. Africans simply would not stand for it - given centuries of external intervention and oppression they place a high premium on political freedom.

Although Korea also received substantial conditional development aid, it worked hard to wean itself off it. The contrast with much of Africa cannot be more stark. Instead of becoming economically independent in the 1960s, African countries have willingly subjected themselves to a relationship of dependency, often appearing to look to others rather than themselves for their development—initially to Europe, today towards China.

\section{The Importance of Labour and Demographics}

Economies grow as a result of increases in the contribution of labour, capital and multifactor productivity to the economy. The latter is generally calculated as the residual or the remaining improvement in the expansion of the economy after accounting for labour and capital and is sometimes also termed the contribution from technology or total factor productivity.

\footnotetext{
${ }^{4}$ Biney, A., 2011. The Political and Social Thought of Kwame Nkrumah. New York: Palgrave Macmillan, see Chapter 1
} 
At low levels of development the contribution of labour to economic growth is most important. For the purposes of this book three components of labour are important namely the absence of widespread ill-health, disease, hunger and malnutrition, a sufficient number of working age persons to dependents (to enable a demographic dividend), and education or improvements in knowledge. Once countries achieve middle-income status the contribution of capital gains in importance which can come from various sources, although generally foreign direct investment would follow domestic investment. Remittances also play an important role in Africa's ability to receive sufficient capital to speed up growth. In high-income economies technology generally drives improvements in productivity, although the exact contribution and calculation of each of these three components is complicated, country-specific and contested.

Many studies have tried to explain why Africa has remained so much poorer than other regions over successive centuries. The continent is richly endowed with commodities, including large land for agriculture and is, after all, the birthplace of our species. But it is exactly for this reason-humanity's origins in Africa - that development here progressed at a slower pace than elsewhere even in recent centuries. Humans only started to multiply once they escaped the high disease risk on the continent where Homo sapiens and nature had coexisted for thousands of years. I explain my understanding of the associated dynamics in Chapter 3 (on health).

In retrospect it is clear that the rapidly increasing size of the labour force in relation to dependents such as that in South Korea, but also in the other Asian Tiger economies, Japan and China was key to their rapid economic growth and development, although other factors certainly also played a role. ${ }^{5}$ Today, several decades later, they all face the opposite problem of a slowdown in growth since a shrinking workforce (as a portion of the total population) has to look after a growing ageing population.

Only since around 1987 has the ratio of working age persons to dependents in Africa started to improve, albeit very slowly. Before that it was declining. As that ratio increases, growth generally accelerates at low levels of development because of the additional contribution that more working age persons make to economic growth. This is discussed in Chapter 4.

Today, the vast majority of African countries are net food importers, despite the continent having millions of hectares of arable land, with huge untapped agricultural potential. Africa imported US $\$ 170$ billion food in

\footnotetext{
${ }^{5}$ Japan bottomed out at a dependency ratio of 0.43 in 1992, China and the Asian Tigers bottomed out at 0.36 in 2010 and 2013, respectively. All experienced their periods of most rapid economic growth in the years during which their dependency ratios were declining.
} 
2018 and exported only US\$67 billion, implying a food trade deficit bill of more than US $\$ 100$ billion. That is expected to increase more than sixfold by $2040 .^{6}$ Exports are dwarfed by the value of imports although a large portion of the increase in imports is due to changed diets as Africans become more wealthy and change their eating habits, reflected in the rise of obesity and non-communicable diseases such as heart conditions hitherto more common in the developed West.

Whereas agriculture is generally considered the mainstay of Africa's economy, yields per hectare are the lowest globally and improving more slowly than in other regions. Since food is cheaper on the international market than domestically and because palates change with income, Africa is becoming more, not less, dependent on food imports.

Furthermore, the impact of climate change is such that it will impact very negatively on the Sahel and West Africa with more variable impacts elsewhere. With very low levels of basic infrastructure such as access to safe water and sanitation, Africa's population is more vulnerable to the impact of climate change than people living in other world regions.

Clearly there is much that can be done to improve agriculture even as it inevitably declines as a share of national economies. Take South Africa for example. Although primary agriculture only contributes about $2.5 \%$ to GDP, South Africa is one of the few African countries that provides food security on the back of a highly productive private agricultural sector, meaning that food imports are dwarfed by exports with sufficient calories available per person.

Looking to the future, the impact of climate change on agricultural yields in Africa is a big uncertainty. Recently, while conducting a long-term forecast on the future of five of the Sahel countries, Mali, Niger, Burkina Faso, Chad and Mauritania, colleagues and I were struck by the impact climate change has already had and will continue to have in this region. The Intergovernmental Panel on Climate Change (IPCC) soberly notes that the Sahel, where agriculture accounts for more than $75 \%$ of total employment, has 'experienced the most substantial and sustained decline in rainfall recorded anywhere in the world within the period of instrumental measurements'.

The impact of climate change will, of course, vary across Africa in terms of changes in temperature and rainfall and the increased variability of weather with many more extreme events such as floods, tornadoes and droughts. That said there is huge potential for technology to increase agricultural production-not through the traditional route of expanding land under cultivation,

\footnotetext{
${ }^{6}$ Calculated by deducting total value of food exports from food imports within IFs 7.45.

7IPCC, 2018. Working Group II Impacts, Adaptation and Vulnerability. [Online] Available at: https:// www.ipcc.ch/working-group/wg2/?idp=403.
} 
but through the use of more precise farming and more sustainable farming methods. Eventually solar-powered cold storage, accurate weather forecasts, monitoring of soil conditions and access to market information can all play an important role, as could greater efficiencies to reduce food waste. However, this will require current practices to change. I explore agriculture in Chapter 5 and the possible impact of climate change in Chapter 15.

\section{Productivity and Economic Structure}

One of the great economic mysteries of our time is why, with all the hype around the impact of artificial intelligence, digitisation, information and communication technologies, labour productivity is not increasing at a greater rate? In the aftermath of the 2008/2009 financial crisis, labour productivity growth has actually slowed in many economies, dropping to an average of $0.5 \%$ in $2010-2014$ from $2.4 \%$ a decade earlier in the USA and major European economies. By 2016 the output per hour of work had actually been declining for more than a decade, argues well-known author and investment fund manager Ruchir Sharma. ${ }^{8}$

In theory the potential for improvements in productivity as part of digitisation and automation is large. But, with a shrinking labour force as a portion of the total population in most middle- and high-income countries, artificial intelligence and automation first need to offset the reduction in productivity from that smaller labour force as a portion of total population before these countries will experience general improvements in productivity. With its growing working age population Africa is potentially in a positive position but is coming off a very low base.

A second reason for low productivity to date is the ongoing shift in the structure of the global economy towards services at the expense of manufacturing. Currently the services sector (lending, recreation, tourism, transport, food) constitutes the largest economic sector by value and is significantly larger than any other sector in Africa, including agriculture and manufacturing. COVID-19 will accelerate this transition as persons working in offices were forced to work from home, using Zoom, Teams and Skype for Business, among others, to communicate, and dedicated conference-goers (like myself) moved to video-conferencing.

Unlike the manufacturing sector, the services sector has not been fully disrupted by technology. Since the service sector is more labour-intensive,

${ }^{8}$ Sharma, R., 2016. The Rise and Fall of Nations-Ten Rules of Change in the Post-crisis World. New York: Penguin Random House. 
the shift to services reduced overall productivity, but that is now rapidly changing although more slowly in Africa given the nature of much of the low-end services, often provided in informal settings.

Many believe that artificial intelligence and automation have the potential to reverse the recent declines in global productivity that have followed the decline in the working age portion of the total population. According to the McKinsey Institute, productivity growth could potentially reach 2\% annually over the next decade, with $60 \%$ of this increase due to digital opportunities. ${ }^{9}$ New 'digital ecosystems' are emerging that combine goods and services in a highly customer-centric manner, shifting the border between these sectors. ${ }^{10}$ Many of these issues are discussed in Chapters 8 and 10 that unpack manufacturing and the potential for Africa to leapfrog.

Being the least developed region in the world, Africa has significant potential for fast improvements in labour productivity through the use of modern technology and practices. Some degree of catching up or even leapfrogging is possible but to date, labour productivity in Africa has been improving much slower than elsewhere and, together with others, I tend towards the belief that an important explanation for the generally slow economic growth of the continent is the fact that the contribution of Africa's already small manufacturing sector has been declining, giving credence to the view that what Africa is experiencing is so-called 'premature deindustrialisation' although there are signs of some recent improvements.

In fact, from already low levels Africa is deindustrialising and becoming even more dependent on low value commodity exports for its foreign exchange earnings. It is the only region globally where the number of commodity-dependent countries (in terms of value of export earnings) increases year on year. ${ }^{11}$

A vibrant manufacturing sector plays a unique role in boosting productivity throughout the economy, thanks to its forward and backward linkages that fuel the development of other sectors such as agriculture and services. 'Manufacturing contributes disproportionately to exports, innovation and growth', writes James Manyika and other authors in a comprehensive 2012

\footnotetext{
${ }^{9}$ Manyika, J., and Sneader, K., 2018. McKinsey Global Institute. [Online] Available at: https://www.mckinsey.com/featured-insights/future-of-work/ai-automation-and-the-future-of-workten-things-to-solve-for.

${ }^{10}$ In a recent article McKinsey Analytics, set out the extent to which the ongoing digital revolution is reducing frictional transaction costs within and across sectors. Atluri, V., Dietz, M., and Henke, N., 2017. McKinsey Quarterly. [Online] Available at: https://www.mckinsey.com/business-functions/ mckinsey-analytics/our-insights/competing-in-a-world-of-sectors-without-borders.

${ }^{11}$ United Nations Conference on Trade and Development (UNCTAD), 2019. State of Commodity Dependence 2019, Geneva. [Online] Available at https://unctad.org/en/pages/PublicationWebflyer. aspx?publicationid $=2439$.
} 
report for the McKinsey Global Institute. ${ }^{12}$ The big question is if African leadership and African workers are prepared for the associated labour practices that accompany this growth path?

Going forward, Africa needs to seize the opportunity offered by renewable energy and the promise of the fourth industrial revolution to rapidly improve productivity growth and to provide many more jobs. But how can that be achieved in a global economic environment where Africa is becoming more, not less, dependent on the export of commodities and where the contribution of its small but growing labour force (as a portion of the total population) is likely of declining value? And all of this while growth of the manufacturing sector is constrained by the fact that Southeast Asia has become the world's factory.

Whereas manufacturing is often referred to as the automatic escalator that lifts countries to higher levels of productivity, Africa appears to be embarking on a low-productivity services and commodity escalator. Africa's services escalator does go upward, but only slowly while the manufacturing window is closing. In addition, it has become much harder to establish export manufacturers as the entire sector is shrinking worldwide and competition is fierce.

Africa's structural transformation from low-productivity, often subsistence agriculture to low-productivity, urban-based retail services in the informal sector has therefore been growth reducing rather than productivity improving. This is largely because the share of workers employed in higherproductivity sectors such as manufacturing is declining, resulting in a drop of the average growth output per worker. ${ }^{13}$

\section{The Global Context}

The challenge of the growing divergence between Africa and the rest of the world is reflected in Africa's marginal role in the global economy. In 1960, Africa accounted for 3\% of the global economy. Sixty years later that share has increased to $4 \%$ despite the fact that Africa's share of the global population

\footnotetext{
${ }^{12}$ Manyika, J., Sinclair, J., Dobbs, R., Strube, G., Rassey, L., Mischke, J., Remes, J., Roxburgh, C., George, K., O'Halloran, D., and Ramaswamy, S., 2012. McKinsey Global Institute. [Online] Available at: https://www.mckinsey.com/business-functions/operations/our-insights/the-future-of-manufacturing. ${ }^{13}$ UNU-WIDER Studies in Development Economics, 2016. Manufacturing Transformation: Comparative Studies of Industrial Development in Africa and Emerging Asia. In: C. Newman, et al. eds. Helsinki: Oxford University Press, p. 5. See also Bhorat, H., Kanbur, R., Rooney, C., and Steenkamp, F., 2017. Sub-Saharan Africa's Manufacturing Sector: Building Complexity, Working Paper Series $N^{\circ} 256$. Abidjan: African Development Bank.
} 
almost doubled from 9 to $17 \%$. Compare this to East Asia and the Pacific, a region that increased its share of global economic output from about $11 \%$ in 1960 to more than 30\% today. East Asia's share of the global population, on the other hand, has shrunk from 34 to $30 \%$ during this period pointing to its much more productive economies.

On current trends it would be safe to refer, by mid-century, to a global economic system that is likely to consist of four centres of power, China, the USA, the EU and a rising India. These countries already account for almost $60 \%$ of global GDP and their share is slowly increasing. By 2040 the Chinese economy should be about 70\% larger than the US economy, which will, in turn, be a bit larger than the EU group of 27 countries (now excluding the United Kingdom). India would then still be about 25 years away from having an economy that is comparable in size to that of the USA although it would have doubled its slice of the global economy to around $7 \%$ and would be growing quickly.

China could constitute one-quarter of the global economy by 2040. This is roughly equivalent to the position the USA occupied around 10 years ago while the USA would see its portion of the global economy decline from the current $21-15 \%$ by then.

But it is unlikely that the world of 2040 will resemble our current obsession with national economies. The future is likely greater regionalisation, particularly in Asia which may increasingly look inward for growth and development rather than to the rest of the world. Already intra-Asia trade surpassed Asian trade with the rest of the world in 2004 and partly protected the region from the impact of the global financial crisis that followed a few years later.

And Asia, in particular, is likely to be much more dynamic than Europe or North America. In this future an economically interdependent and integrated Asia will become more important.

Asia is, of course, hugely diverse including a group of advanced economies such as Japan, and South Korea, the two giants (China and India), a group of large countries such as Indonesia and Bangladesh and a group of poorer countries that includes Afghanistan, Bhutan and Papua New Guinea. ${ }^{14}$

On the Current Path forecast Africa is likely to remain a peripheral player in this world, although its share of the world's population will increase very quickly. By 2040 Africa's population will have crossed the two billion mark and be significantly larger than the population of India or China. In fact, Nigeria alone would have a population of 360 million by 2040, making it

\footnotetext{
${ }^{14}$ According to Economy Watch, 2019. Developing Asia (Emerging and Developing Asia) Economic Statistics and Indicators. [Online] Available at: http://www.economywatch.com/economic-statistics/cou ntry/Developing-Asia/.
} 
the fourth most populous country globally after India, China and the USA. But because of poor growth prospects, Nigeria will account for less than $1 \%$ of the global economy and is unlikely to emerge even as a global middle power.

Figure 1.3 presents the total populations of key countries and groupings namely Africa, China, India, the EU27, USA and the rest of the world at twenty-year intervals from 1980 to 2040. Africa's population size is set to rapidly increase over the time horizon set out in this book.

Although Africa's population is set to increase from its current $17 \%$ of the global population to $23 \%$ by 2040 , the continent will then only represent $4 \%$ of the global economy. And Asia, knitted together by China's Belt and Road Initiative, an infrastructure superhighway, will have more than double the population of Africa.

Figure 1.4 presents the same countries and groupings as in Fig. 1.2, also with 20 year time intervals, this time presenting the size of each economy in market exchange rates.

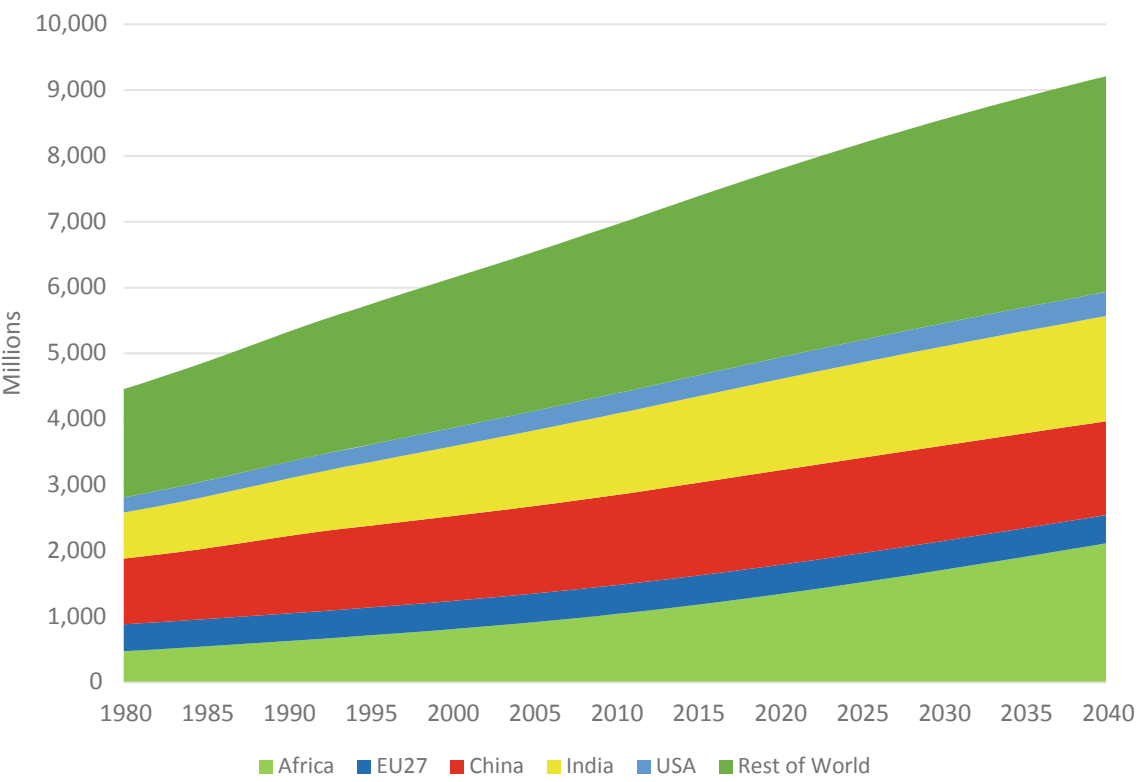

Fig. 1.3 Composition of the global population: 1980-2040 for Africa, China, India, EU27, USA and the Rest of the World (RoW) (Source Historical data from United Nations Population Division, forecast in IFs 7.45) 


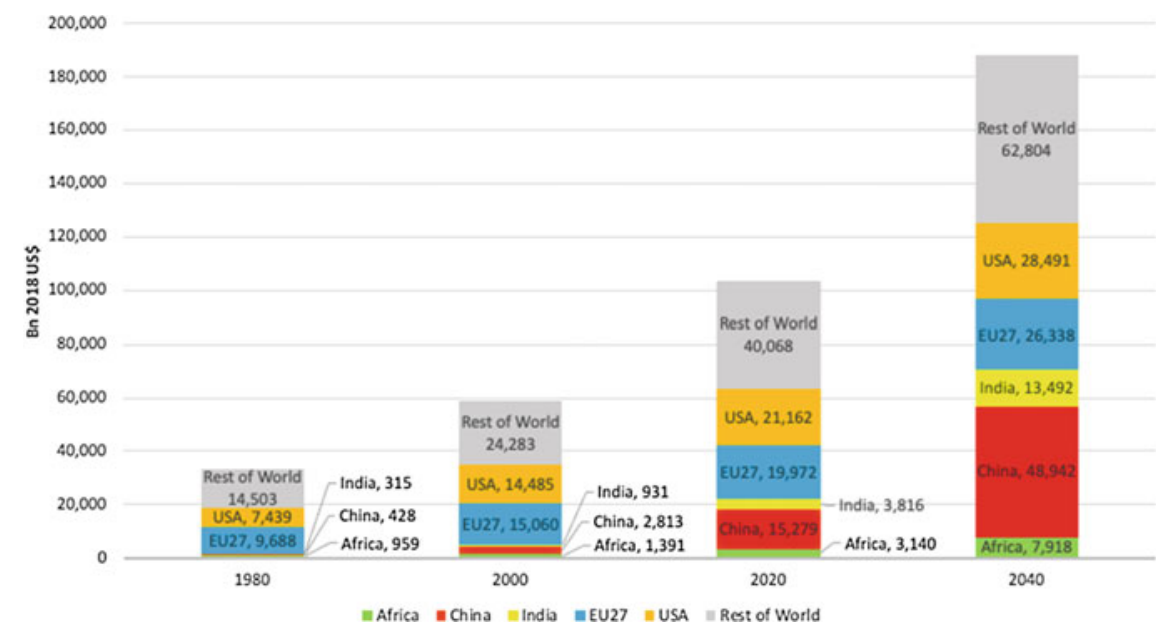

Fig. 1.4 Comparing economies: 1980-2040 (Source Historical data from IMF World Economic Outlook, forecast in IFs 7.45)

\section{Dealing with Africa's Diversity-Using Country Income Groups}

A book of this nature can hardly do justice to the rich diversity of Africa, its 55 states, thousands of languages and many different cultures.

For the most part, I use the 2019/2020 World Bank groupings of low, lower-middle and upper-middle-income groups to explore trends across countries at roughly similar levels of development. ${ }^{15}$ Of 31 low-income countries around the world, 24 are in Africa. And African countries account for 21 of the 47 low-middle-income countries globally. Africa has only eight (out of 60) upper-middle-income countries namely Algeria, Botswana, Equatorial Guinea, Gabon, Libya, Mauritius, Namibia and South Africa. Of 80 highincome countries, only one is in Africa, the island state of Seychelles and I largely ignore it in what follows.

These classifications are particularly useful to compare the structure of economies, levels of income, education and access to infrastructure between countries at roughly the same levels of economic development. Where appropriate, I benchmark Africa to the rest of the world within these categories such as comparing averages in low-middle-income Africa with that for the average for low-income countries globally or for low-middle-income countries in the rest of the world (Fig. 1.5).

\footnotetext{
${ }^{15}$ For its 2020 fiscal year. See World Bank Country and Lending Groups. Available at https://datahe lpdesk.worldbank.org/knowledgebase/articles/906519-world-bank-country-and-lending-groups.
} 
GDP in billion 2018 US\$

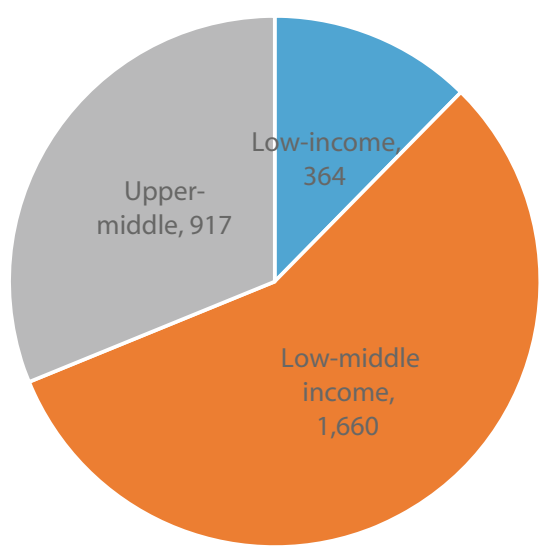

Population in millions

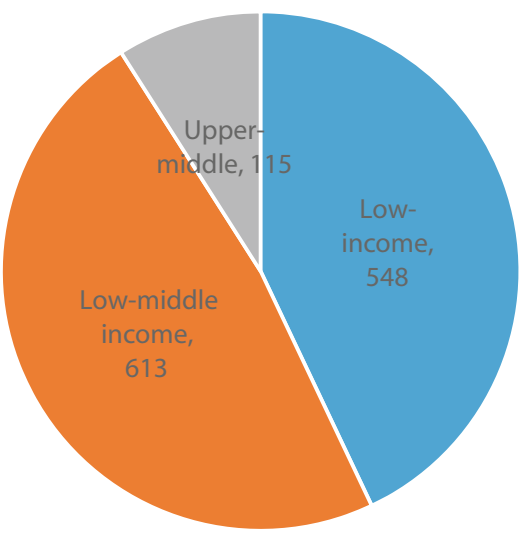

Fig. 1.5 Economic size and population size for low, lower-middle and upper-middleincome Africa in 2018 (Source UN Population Division and IMF World Economic Outlook data in IFs 7.45)

Generally low-income countries grow more rapidly, so the average economic growth forecast from 2020 to 2040 for Africa's 24 low-income countries is $6.7 \%, 5.1 \%$ for the 21 low-middle-income countries and $2.6 \%$ for Africa eight upper-middle-income countries.

Occasionally, I look at Regional Economic Communities (RECs) such as the East African Community (EAC), the Southern African Development Community (SADC) or the Economic Community of West African States (ECOWAS). Since many of these communities have overlapping membership I define Africa's five geographic regions as follows (see Fig. 1.6):

- North Africa: Algeria, Egypt, Libya, Mauritania, Morocco and Tunisia.

- West Africa: Benin, Burkina Faso, Cape Verde, Côte d'Ivoire, The Gambia, Ghana, Guinea, Guinea-Bissau, Liberia, Mali, Niger, Nigeria, Senegal, Sierra Leone and Togo.

- East/Horn of Africa: Burundi, Comoros, Djibouti, Eritrea, Ethiopia, Kenya, Madagascar, Mauritius, Rwanda, Seychelles, Somalia, Sudan, South Sudan, Tanzania and Uganda.

- Central Africa: Cameroon, CAR, Chad, DRC, Republic of Congo, Equatorial Guinea, Gabon and São Tomé and Príncipe.

- Southern Africa: Angola, Botswana, Lesotho, Malawi, Mozambique, Namibia, South Africa, eSwatini (Swaziland), Zambia and Zimbabwe. 


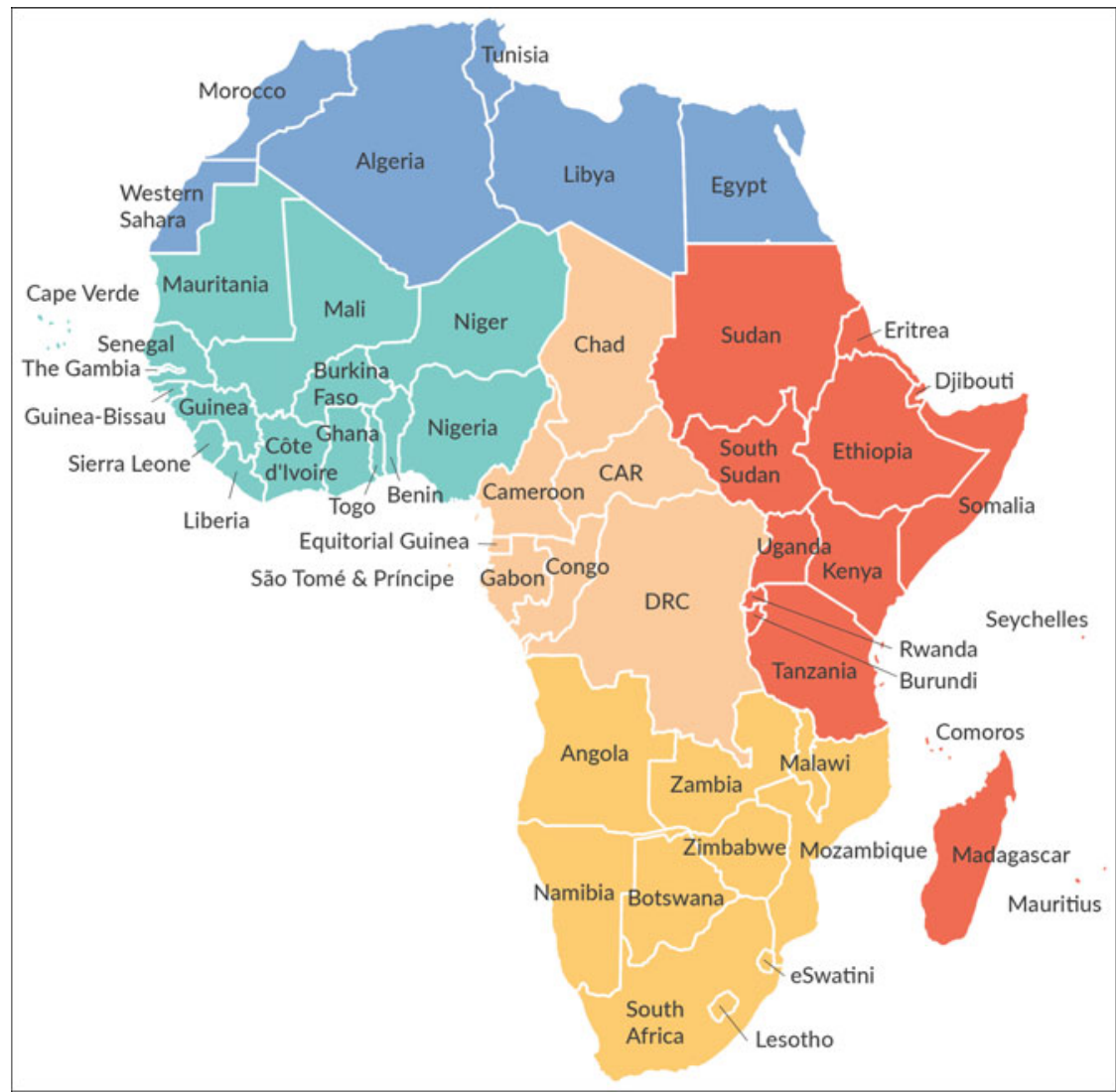

Fig. 1.6 Regions in Africa

These categories are exclusive in that no country belongs to more than one geographical region.

Looking at the average rates of economic growth for these five regions, East/Horn of Africa is set to experience the most rapid economic growth from 2020 to 2040, at 6.3\%, followed by West Africa at 5.5\%. Northern and Southern Africa will grow at 3.7 and 3.8\%, respectively, and Central Africa at $4.7 \%$. Over this period the population of Central Africa is expected to increase by $75 \%$, however, meaning that average GDP per capita in purchasing power parity in this region will only increase by US $\$ 840$ from 2020 to 2040. The population in West Africa will increase by $68 \%$ and, by 2040, West Africa will have a GDP per capita that is US\$2270 larger than in 2020. The number for East/Horn is a $60 \%$ population growth and an increase in GDP per capita of US\$1890. The population of Southern Africa will increase by $50 \%$ and, by 2040 , it will have a GDP per capita that is 
US $\$ 2035$ bigger than in 2020 . The population of North Africa will increase by only $25 \%$ and, because it includes a number of upper-middle-income countries, therefore coming off a higher base, by 2040 it will have a GDP per capita that is US\$4020 larger than in 2020.

In summary, this is a picture of Central Africa that, with each passing year, falls further and further behind the rest of the continent. Average income growth will be highest in North Africa followed, at some distance by West and Southern Africa with East/Horn of Africa trailing slightly behind.

There is, of course, a limit to the utility of these regional comparisons since each region includes countries at very different levels of development and with unique population and income characteristics, such as the very high levels of inequality in Southern Africa compared to the rest of Africa (and the lowest average levels of inequality in North Africa compared to other regions in Africa).

In the interest of standardisation, all US dollar figures taken from the International Futures forecasting system (see below) and used in this book (such as those on GDP per capita in the previous paragraphs) have been converted to 2018 values. Unless indicated otherwise, figures and data presented in the various chapters are estimates taken from IFs for 2018 is used as a general reference year throughout, also when using material from other sources. ${ }^{16}$

Finally, I sometimes compare Africa with two other developing regions, namely South America and South Asia, ${ }^{17}$ that align most closely on a host of development indicators except in agricultural yields where South America is close to a global leader.

\section{Previous Studies and the International Futures Forecasting Platform}

Long-term trends are affected by deep drivers that are slow-moving but powerful, like demographics, education or commodity super cycles, which also unfold over decades. These deep drivers are increasingly well understood

\footnotetext{
${ }^{16}$ The rate of conversion from the 2011 US\$ values in IFs to 2018 prices is 1.1163 . Where no data is available for 2018, I use the forecasts from the International Futures forecasting platform (IFs, which initialises from 2015 values) but make no distinction in the use of the term data or forecast. Since the IFs forecasts generally demonstrate a high level of continuity with historical trends, the forecasts are a close representation of reality and likely paint a more accurate picture than 'most recent data', which can often be several years old.

${ }^{17}$ Within IFs South America consists of Argentina, Bolivia, Brazil, Chile, Columbia, Ecuador, Guyana, Paraguay, Peru, Suriname, Uruguay and Venezuela. South Asia includes Afghanistan, Bangladesh, India, Iran, Maldives, Nepal, Pakistan and Sri Lanka.
} 
in forecasting literature, even though the exact contribution and sometimes the direction of causality remains a subject of intense academic debate. Some prospects, such as demographics, are easier to forecast than others, like the potential impact of technology or how changes in governance may evolve, but none are impossible.

When all is said and done, it is much more useful to spend time and effort on systematically exploring plausible futures than relying on speculation or gut-feel. Which brings me to another important characteristic of the type of forecasting that follows, namely that each chapter is based on realistic expectations of what could be possible (benchmarked against historical precedent) instead of a desired future. This is not a blue-skies book on where I would like to see Africa, but on what could realistically be possible given the right policy choices, clear leadership and determined implementation.

The forecasts in this book rely on the International Futures (IFs) modelling platform that is developed and housed at the Frederick S Pardee Center for International Futures at the Josef Korbel School of International Studies at the University of Denver. The model is open source and is available for download at the Pardee Center website at https://pardee.du.edu/access-ifs.

Each of the following chapters compare the IFs Current Path forecast with a set of interventions grouped as a coherent scenario. The Current Path is an integrated forecast (or scenario) of the likely future development trajectory. In other disciplines it is also known as the Base Case or Business as Usual forecast. It does not assume any major paradigm shifts, seismic policy changes, or transformative events such as global war, pandemic (such as COVID-10) or cataclysmic climate change tipping point. In other words, it is not a forecast that anticipates very low probability but high impact events, although one can create scenarios within IFs that emulate anything from global war to drought, or swift technological progress. Rather, the Current Path represents a reliable expectation of how major development systems are likely to unfold, and is a useful starting point from which to design alternative future scenarios.

The details of the modelling and the specific levers pulled within IFs can be found at www.jakkiecilliers.org that also details the benchmarking of each intervention, as well as the adjustments that have been made in the IFs Current Path forecast for the purposes of this book.

The forecasts presented in this book are sure to be wrong in many respects. Beyond our limited ability to understand the evolution of human, environmental and other systems, data from many African countries are poor or even absent. Fortunately, the quality of international data gathering is improving as the efforts to improve statistical service agencies bear fruit. Governments 
also more regularly recalculate the overall price structure of their economies. To that end the African Union and various partners have embarked on a Strategy for the Harmonization of Statistics in Africa (SHaSA), now in its second strategic period with a time horizon from 2017 to $2026 .{ }^{18}$

In 2014 alone, Kenya, Nigeria, Tanzania, ${ }^{19}$ Uganda and Zambia all completed economic rebasing exercises, which led to significant revaluations of their GDPs. Nigeria's (2013) GDP nearly doubled and the country overtook South Africa as the largest economy in Africa when measured in market exchange rates. The increase of about $90 \%$ in the size of the Nigerian economy was attributed to the inclusion of new sectors of the economy such as telecommunications, the burgeoning local film industry (known as Nollywood), the retail and informal sectors.

The calculations also revised the size of Kenya and Zambia upward by a quarter and the World Bank categorised Kenya from a low-income to a lower-middle-income country. Ghana found that its economy increased by $60 \%$ when the previous rebase was announced in 2010 — and by another $25 \%$ when the latest rebase was announced in 2018. When Zimbabwe rebased its economy in 2018 it also concluded with a $40 \%$ increase in the size of its economy, much of which was now sadly part of the informal rather than the formal sector. Country classifications also go the other way. In contrast to Kenya, Zimbabwe was downgraded from lower-middle to low-income in 1991, but was again reclassified as lower-middle in mid-2019. ${ }^{20}$

Finally, since data for Africa is often incomplete, the IFs system has a preprocessor-a sophisticated series of algorithms-that estimates and fills data gaps. In this manner the model is able to provide a solid foundation for each of the 500 or so variables that are forecast for each country.

In all instances where data is provided without a reference in the form of an endnote, the reader should assume that the data comes from IFs.

\footnotetext{
${ }^{18}$ African Union Commission; African Development Bank; United Nations Economic Commission for Africa; African Capacity Building Foundation, 2017. Strategy for the Harmonization of Statistics in Africa 2017-2026 (SHaSA 2). [Online] Available at: https://www.tralac.org/documents/resources/ african-union/2031-strategy-for-the-harmonization-of-statistics-in-africa-shasa-2017-2026/file.htm.

${ }^{19}$ The 2019 rebase of Tanzania to 2015 found that its economy had increased by $3.8 \%$. Reuters Africa, 2019. Tanzania Rebases Economy, 2015 GDP Now 3.8 pct Larger-Stats Office. [Online] Available at: https://af.reuters.com/article/investingNews/idAFKCN1Q91G0-OZABS.

${ }^{20}$ Sy, A., 2015. Brookings. [Online] Available at: https://www.brookings.edu/blog/africa-in-focus/ 2015/03/03/are-african-countries-rebasing-gdp-in-2014-finding-evidence-of-structural-transformation/; Benghan, B., and Noshie, A., 2018. AllAfrica. [Online] Available at: https://allafrica.com/stories/201 810010595.html; Musarurwa, T., 2018. The Herald. [Online] Available at: https://www.herald.co. zw/economy-rebasing-to-grow-zim-revenue/.
} 


\section{Structure of the Book}

In addition to some characteristics already presented in this chapter, Chapter 2 presents the Current Path forecast for Africa to 2040 and serves as a broad overview for the eleven scenarios, each in a separate chapter, on health, demographics, agriculture, education, poverty, manufacturing, leapfrogging, trade, security, governance and external support. Chapters 9 and 15 do not have separate scenarios, but compares the impact of key scenarios on the future of jobs and the impact of climate change. Chapter 16 concludes and includes the impact of a combined scenario ("Closing the Gap"). It shows what could be possible by 2040 and compares those outcomes with the Current Path trajectory.

The book adopts a structured approach to Africa and the analysis builds from one chapter to the next, although some chapters can be read in a different sequence. But what Africa needs is the combined impact of all of the interventions across the different sectors and hence there is no shortcut to either a better future or to this book but to read it all.

\section{Further Reading}

www.jakkiecilliers.org.

www.issafrica.org.

www.pardee.du.edu.

Open Access This chapter is licensed under the terms of the Creative Commons Attribution 4.0 International License (http://creativecommons.org/licenses/by/4.0/), which permits use, sharing, adaptation, distribution and reproduction in any medium or format, as long as you give appropriate credit to the original author(s) and the source, provide a link to the Creative Commons license and indicate if changes were made.

The images or other third party material in this chapter are included in the chapter's Creative Commons license, unless indicated otherwise in a credit line to the material. If material is not included in the chapter's Creative Commons license and your intended use is not permitted by statutory regulation or exceeds the permitted use, you will need to obtain permission directly from the copyright holder.

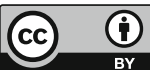

